\title{
Lessons from Objects: Designing a Modern Hungarian Childhood, 1890-1950
}

\section{Amber Winick}

\begin{abstract}
Art and architecture assisted Hungary's delivery into modern Europe, and many Hungarian designs of the early twentieth century invoked the child rather than the adult as the ideal citizen. Throughout the first half of the twentieth century, Hungarian designers, design reformers, and the Ministry of Culture and Education expressed national identity through design, emphasizing objects and spaces for children as a key element in defining a national culture. This research unfolds a vital dimension of Hungarian culture by examining a selection of objects and spaces-nursery designs, children's clothing, school architecture, the Budapest Zoo and book illustrations - made for Hungary's children during different periods of the last century. Working in partnership with the Iparmüvészeti Múzeum - the Museum of Applied Arts in Budapest - as well as several public and private collections across Hungary, I researched a number of important children's designs that helped to shape the lives and experiences of twentieth century Hungarian children. Central to my research is how social and political forces shaped designs and how these designs helped children identify as Hungarian citizens. Looking at six material case studies, I hope to demonstrate the ways in which designers negotiated issues of Hungarian identity, tradition, and modernity.
\end{abstract}

Keywords: Central European Studies, Hungarian Design and Architecture, Design History, Material Culture of Childhood, Objects and Education, Developmental Psychology, Environmental Psychology, National Identity, Identity Formation, Applied Art, National Romantic Style, Nationalism and Childhood.

Biography: Amber Winick is a specialist in twentieth century design and the history of education. She received her B.A. from Sarah Lawrence College (2003) and her M.A. from the Bard Graduate Center (2013). In 2014 she received a Fulbright Research Award for her work on intersection of child-centered design and Central European history.

Around the turn of the twentieth century, a number of interrelated occurrences - design's role in the delivery of modern Hungary, a desire to assert a conscious national identity and an increased focus on children-began to occupy Hungarian consciousness in new and fascinating ways. Through the Austro-Hungarian Empire, the devastating conflicts of World Wars I and II, the Treaty of Trianon, the Communist era, and the formation of the modern Hungarian Republic, Hungarian designers, design reformers, and the Ministry of Culture and Education expressed 
national identity through design, emphasizing objects and spaces for children as a key element in defining a national culture. By looking across a spectrum of designs and activities, this article examines how Hungarian designs made for children conjured a sense of material nationality, educated children, and provided a touchstone for Hungarian culture. At the same time, I argue that these objects were shaped by larger ideologies, cultural preoccupations, and social and political events. In what follows, I will examine a number of key Hungarian designs made during the first half of the twentieth century - a design for a nursery, a girl's bodice, a school, a zoo, an illustrated story, and an alphabet book — as well as the shifting cultural landscape that facilitated these creations.

The idea that children are mutable, impressionable, and have the potential to grow into the citizens of tomorrow is, historically speaking, a relatively recent concept. The turn of the twentieth century brought a fresh view of childhood, and the view that children could transform into model citizens took hold across several stratum of modern society-everyone from city planners, to educational reformers and communist officials espoused the advantages of nurturing the ideal child (Kinchin and O'Connor 2012: 50-53). Across the United States and Europe, the newly developing Progressive Era paved the way for innovative ideas about the relationship between public policy and daily life. The Swedish educational reformer Ellen Key declared the twentieth century "The Century of the Child" and fresh concepts surrounding children inspired ground-breaking attitudes toward education, design, and aspects of political life (see Gutman and de Coninck-Smith 2008 and Key 1909). By the opening years of the twentieth century, Hungary had undergone a period of rapid industrialization and occupied a relatively privileged position within the Hapsburg Empire as a partner in the so-called Dual Monarchy that joined Austria and Hungary. Despite the economic advantages and political autonomy this afforded, however, it was a partnership very much dominated by Austria. In response to this imbalance, the Hungarian government increasingly sought to challenge Austrian hegemony by reinforcing aspects of daily life that expressed a conscious Hungarian national identity. Though in many ways Austria and Hungary shared a common artistic heritage, Magyar culture - everything from music to language to architecture - was increasingly isolated as a more true Hungarian expression, and was promoted as indigenous to the territory (Anderson 1983: 83-85).

The Hungarian government encouraged ambitious participation in world's fairs and other exhibitions abroad, as well as the promotion of Hungarian national style in large civic architectural projects that were intended to mark Budapest as a world capital (see Switzer, T. 2003). As elsewhere in Europe, the National Romantic-style incorporated early medieval and prehistoric building styles with new architectural forms, constructing a style appropriate to the perceived character of a nation.

In 1906, the architect Ödön Lechner (b. 1845) wrote:

Hungarian formal language has not been, but will be. Because it has to. This conviction leads my career, whose aim is to blaze a trail in the institution of a Hungarian formal language, and whilst I strive to achieve this ideal with irrevocable faith and absolute ardor, and with the support of my comrades who increase from one day to the next, I search for strength, and I find it, not only in my patriotic fervor, but also in my artistic certitude. This is the point at which art and politics meet (Lechner 1906). 
Winick, Amber. "Lessons from Objects: Designing a Modern Hungarian Childhood 1890-1950.” Hungarian Cultural Studies. e-Journal of the American Hungarian Educators Association, Volume 8 (2015): http://ahea.pitt.edu DOI: 10.5195/ahea.2015.216

[Magyar formanyelv nem volt, hanem lesz. Mert kell lennie. Ez a meggyözödés vezet életpályámon, amelynek egyetlen célja utat vágni a magyar formanyelv megalakitása felé, —és mialatt törhetetlen hittel és minden buzgalommal azon vagyok, hogy napról-napra szaporodó bajtársaim segedelmével ezt az eszményt elérjem, erő́t keresek és találok nemcsak hazafias lelkesedésemben, hanem müvészi meggyözödésemben is. Ez az a pont, ahol müvészet és politika találkozik.]

In his 1890s design for Iparmüvészeti Múzeum - the Museum of Applied Art—Lechner found the opportunity to put his architectural and artistic-philosophical ideals into practice. He utilized new technology and materials - such as Hungarian Zsolnay ceramic tiles - and blended traditions of the Indies and Islam in his design. By doing so Lechner took the first step in the formation of a particularly Hungarian style, which coincided with, even slightly anticipated, the development of European Art Nouveau (Howard 1996: 123-181). The façade of the Iparművészeti Múzeum's large, oriental-style dome has motifs directly transposed from Magyar folk embroidery patterns (image 1). Above a footing of red marble, almost the entire façade is clad with frost-proof poly-granite with ornamental inserts of glazed brick. In front of the main entrance is an open space surrounded by columns clad with poly-granite, reminiscent of Indian rock-temples, while the ceiling references an oriental carpet rendered in ceramic. With the foiled-ogive vaulting of its lofty row of columns, the sweeping central exhibition hall is punctuated with Moorish architectural lines and details, placing a sense of eastern exoticism into the Hungarian visual lexicon (image 2).

As an architect and theorist, Lechner's designs were earnest, lofty, and not altogether popular with his contemporaries. Still, he remains a giant in Hungarian design, and has influenced generations of designers and architects. Lechner's designs and design theories effectively set into motion the search for Hungarian national style (see Kesaru and Haba 2003).

Under his influence, twentieth century Hungarian designers referenced Asian and Islamic designs, claiming far-flung places as part of the Hungarian identity. Lechner also incorporated vernacular Hungarian designs and the folk arts into his visual repertoire. Transcending particular regional variations with an amalgam of 'Hungarian' sources, Lechner developed a historicallybased aesthetic that was made modern with the use of cutting-edge materials and building techniques.

For Hungarians living on either side of the twentieth century, the folk arts were completely magnetic and perceived as a true expression of Magyar culture. From architecture to furniture to book covers, designers drew on typical folk embroidery patterns and vernacular wooden architecture, including traditional carpenter detailing in the plank construction, tulip cutouts, and notched and chamfered decoration. The wooden spire in particular assumed iconic significance for generations of National Romantic-style architects and designers (Kinchin 2002: 65-93).

In an increasingly urbanized and industrialized world, the folk arts also represented a life closer to nature. By 1900, Budapest had a population of seven-hundred-and-fifty-thousand, making it the second largest city in the central European Hapsburg lands and the seventh largest city in Europe (Howard 1996: 123-181). While the spirit of progress fostered developments in building and industry, there was an equally profound longing to recapture the essence of Hungary through a return to a simpler, more authentic way of life, and one closer to the earth. 
Winick, Amber. "Lessons from Objects: Designing a Modern Hungarian Childhood 1890-1950.” Hungarian Cultural Studies. e-Journal of the American Hungarian Educators Association, Volume 8 (2015): http://ahea.pitt.edu DOI: 10.5195/ahea.2015.216

As Hungary entered the modern age, the countryside played a prominent symbolic role. For conservative nationalists and liberal designers alike, the Hungarian countryside became a symbol and source of authentic, "traditional" Hungarian national culture, and of unchanging, hierarchical, ordered society and stable community, and national uniqueness. Designs made for children provided alternative representations of the countryside that upheld the possibility of modernizing traditional Hungary. Particularly because children aged into adulthood, modern Hungary would be created at the intersection and out of the cooperation between rural and urban, modern and traditional. Childhood, like nature, was perceived as "pure," authentic, untainted. Modern designs made for children were implicitly future oriented and rejected the idea that the rural was shameful, hopelessly backward, or unable to change. Showing the countryside as both traditional and part of modern mass culture, as both nostalgically stable and exotic, many of Hungary's best designs for children offered an integrative vision of Hungary that provided an outlet for a cultural perspective unavailable elsewhere in the public sphere.

István Bárczy (b. 1866) was the mayor of Budapest from 1906 to 1918 and also served in the Ministry of Culture and Education. During his career, Bárczy embarked upon an ambitious program of architectural commissions, many of which were centered around children (Kinchin and O'Connor 2012: 51-53). As mayor, he oversaw the construction of a great many spaces for children, including parks, playgrounds, and the Budapest Zoological Gardens, as well as fifty-six schools (Kinchin and O'Connor 2012: 53). One of the most successful child-focused Bárczy ventures was the Gödöllö Arts and Crafts Colony. Named after the town of Gödöllö, located twenty miles northeast of Budapest, between 1901 and 1920, a group of artists and designers flocked to the area in search of a creative and philosophically rich lifestyle. Inspired by the Englishman William Morris's (b.1834) craft ideals and a simpler, more rural life in the face of industrialism and urbanization, the Gödöllö artists were also concerned with the creation of artful way of living that would infuse daily life with beauty, spirituality, and meaning. They grew their hair and beards long, wore sandals, ate a vegetarian diet, swam and sunbathed in the nude, and lived close to the earth and in tune with the seasons. Living close to nature was very much a part of their overall philosophy and lifestyle, and inspired their vision of life and what it should look like.

In search of a complete expression of their artistic, social, and spiritual beliefs, the Gödöllö artists saw the Colony as a collaborative Gesamtkunstwerk - a unified work of artwhich would be created by every Colony member in every medium, from buildings and stained glass to clothing and toys. Family life was central to the artist's daily routines as well as their artwork; the Gödöllö artists believed that an artistic education must begin in childhood and aesthetic objects and spaces should surround children. They saw good design as having the potential to foster a sense of morality, spirituality, and even nationality. These guiding principles were very attractive to the municipal authority, which increasingly sought to promote a distinct Hungarian visual identity. As Aladár Körösföi Kriesch (b.1863) said at an exhibition of Gödöllö arts and crafts at the Budapest National Salon in 1909, "We love others when we consider ourselves the small offshoots, leaves or flowers of the great common tree of life. What our dayto-day work produces in the light of this jubilant joy in living is our art. We know no other artistic program" (Gellér and Bitter 1987: 16). Members of the Gödöllö Colony were concerned with making art and design that was culturally distinct, and Bárczy must have recognized the great potential in presenting technically and aesthetically modern versions of traditional Hungarian folk design. 
Winick, Amber. "Lessons from Objects: Designing a Modern Hungarian Childhood 1890-1950.” Hungarian Cultural Studies. e-Journal of the American Hungarian Educators Association, Volume 8 (2015): http://ahea.pitt.edu DOI: 10.5195/ahea.2015.216

The radical socialism that informed the Gödöllö artists' pronouncements was also reflected in their unconventional dress. As in other progressive cities, the artistic set dressed in a way that allowed for freedom of movement and the Gödöllö artists' designs for their own children's clothes liberated young bodies from the tyranny of tight-fitting, elaborately tailored clothing (Kinchin and O'Connor 2012: 50-53). Laura Kriesch's (b. 1879) bodice, designed and embroidered for her own young daughter, is a modern innovation on an earlier folk design (image 3). Expanding on the typical folk embroidery pattern of a silhouetted bird, Kriesch renders her bird delicately. Her stitches are small and tight, and her palate-muted purples, greens, yellows, oranges, and pinks set against a coarsely woven linen background - strays from the typical reds and blues and wide stitches seen in traditional Hungarian folk embroidery. The embroidered bird is pictured in mid-flight, underscoring the physical and spiritual freedom within the garment's from. Wearing clothing that incorporated traditional decoration within an entirely new, and looser design, Kriesch's daughter was emancipated from the bondage of yesteryear; yet, as her body attested, she embodied time-honored traditions and was at the cusp of modernism.

The Gödöllö artist Mariska Undi's (b. 1877) interior scheme for a child's room combined references to colorful, traditional folk culture with a response to international artistic currents and modern methods of production and distribution (Kinchin and O'Connor 2012: 50-53) (image 4). Along with many other designs for children, Undi's scheme was published as a pattern sheet by the Ministry of Culture and distributed around the country for reference and replication in elementary and specialist schools as well as in factories and workshops. An example of the nursery was replicated at the Louisiana Purchase Exposition in St. Louis in 1904, where it attracted international attention as an example of the distinctive modern craft idiom being developed in Hungary (Kinchin and O'Connor 2012: 50-53). Like the other interior designs produced by the Gödöllö Colony, Undi's nursery encourages free and open-ended interaction between adults and children. With the furniture's plank construction and carved wooden designs and the abstracted, embroidery-inspired patterns, the design is a model for reform in daily life and in domestic design. Undi's nursery design was meant to encourage spontaneity and pleasure, and even remind adults to let their creativity flourish, reaffirming their own self-sufficiency amidst nature. Undi's design also typifies the purposeful balance between tradition and modernism that Hungarian designers from the turn of the century were concerned with.

While Bárczy gained a reputation for supporting innovative artists and designers during his tenure in city government, his legacy was hugely impactful in the area of school design. One of his first commissions was a school on Dob utca designed by Ármin Hegedüs (b. 1869) in 1905 (image 5). Hegedüs was a faithful follower of Lechner and greatly valued a patriotic upbringing. He was convinced that the internal and external decoration of a school building and its functional arrangement must take into account children's health and comfort and their aesthetic and educational requirements. Every detail was considered in the design - benches were made according to pupil's height at various ages, while lighting in the classroom was neither too bright nor too dark. The brick ribbons around the windows, characteristic of Lechner, complement the decorative brickwork on the façade and reference Hungarian embroidery patterns. The mosaics reference Bruegel's children's games, albeit a modern reinterpretation and in a Hungarian spirit. On the left, young girls are pictured singing and embroidering while on the right, the young boys are playing soldiers, reading, and studying the terrestrial globe. In the center, a different group of girls and boys play blind man's bluff. These kinds of National Romantic-style building projects 
Winick, Amber. "Lessons from Objects: Designing a Modern Hungarian Childhood 1890-1950.” Hungarian Cultural Studies. e-Journal of the American Hungarian Educators Association, Volume 8 (2015): http://ahea.pitt.edu DOI: 10.5195/ahea.2015.216

sealed Budapest's reputation as an international city run by a progressively minded municipal authority. The buildings also familiarized young people with their cultural heritage by creating fanciful spaces that they would recognize as Hungarian: the shape of the windows and overall building, the color palate, the mosaic — each of these features was part of a Hungarian visual lexicon in a place where children spent a great deal of time.

While schools did the work of familiarizing young Hungarians with aspects of their culture, the Budapest Zoo, though it was built to house animals, was largely designed for the benefit of young visitors. After undergoing a large-scale renovation that lasted nearly four years, the Budapest Zoo reopened to the public with a completely new design in May of 1912. Károly Kós (b. 1883) and Dezső Zrumeczky (b. 1883), the two young and promising architects who were commissioned to redesign the Zoo, created designs that would cement Budapest's place within modern Europe and cultivate Hungarian allegiance. Though they just graduated from architecture school, Kós and Zrumeczky already had a reputation for blending folk sources with modern building techniques.

By the early 1900s, the fad in zoo design was to move away from cages, and instead build enclosures that mimicked animals' natural habitats (see Baratay and Hardouin-Fugier 2002). But Kós and Zrumeczky took the notion of 'natural habitat' into unchartered territory when they envisioned the Zoo as a Transylvanian village, perceived as the "natural habitat" of Hungarians. Between 1909 and 1912, Kós and Zrumeczky designed sixteen Zoo pavilions to replicate aspects of the Transylvanian countryside, and in doing so created one of the most complete expressions of Hungary's early twentieth century architectural spirit (Gall 2002: 146194).

Capitalizing on the expanse of green space, the design team installed undulating hills, mountainous cliffs, and a lake. The meandering paths offered opportunities to relax, stroll, and enjoy the fresh air. Just as in Kalotaszeg, the village atmosphere of the Zoo would have romantic castle ruins in the distance (image 6). Though they were recreations, these structures would materially imprint Romanesque castles into Hungary's visual lexicon. The Castle Ruins, with their thick stonewalls, crumbling piers and towers, and round symmetrical archways, made homes to Hungarian dogs - pulis, punis and vizslas. Located along the edge of the Zoo, the castle ruins also provided a boundary between the Zoo and the railway station, located just over the rocky mounds. Designed to replicate a Transylvanian village, many of the Zoo's buildings were essays on a particular theme. The tall wooden spire of the Bird House became the village church, while the fantasy of the Poultry House, for example, was a typical family farm (Gall 2002: 146194) (image 7).

In addition to the visual rhetoric behind the Zoo's built environment, educational programs provided children with an experiential sense of Hungarian life. Shortly after the 1912 reopening, groups of schoolchildren were invited to the Poultry House to collect eggs from chickens and to cultivate honey from bees (Persányi 2003: 34). Though the lessons were informal and lighthearted, children did more than play - they performed adult tasks that required concentration, skill, and physical stamina. Fusing the rural and the urban, as well as the distant past with the palpable present, action-based educational programming connected children to activities their rural ancestors might have participated in. Such educational programs echoed the beliefs of Fredrich Froebel - pioneer of the kindergarten movement in Germany in the 1830swho emphasized that "the starting point of all human culture, also of knowledge is doing, action. Action must be the starting point of the real, the developing education" (Froebel 1826 quoted in Jarvis 1885: 30). Froebel's beliefs were complementary to Kós's, who touted the benefits of the 
Winick, Amber. "Lessons from Objects: Designing a Modern Hungarian Childhood 1890-1950.” Hungarian Cultural Studies. e-Journal of the American Hungarian Educators Association, Volume 8 (2015): http://ahea.pitt.edu DOI: 10.5195/ahea.2015.216

rural Kalotaszeg experience. For Kós, the rural communities of Transylvanian peasants had preserved the nature of Hungary in their material culture, and he felt that experiencing their way of life was a necessary right of passage for Hungarians:

It is essential to live amongst the (Kalotaszeg) folk, to find their spirit, to transport into our conscious art that which is unconsciously and instinctively Hungarian...As if the past had yet to pass and were living together perpetually with the present. Past and present flow together here in indivisible unity, only thus together does it render a whole. These people are one and the same as those who once lived here, day-by-day their endeavors are exactly those of their forefathers, and their forebears lived just as their descendants live today. And as it was one in the past so it will be in the end also: the leafy churchyard behind the church and a grassy hill crowned with a carved grave marker (Gall 2002: 37-38).

Kós and Zrumeczky's designs for the Budapest Zoo recreated this utopic vision of Kalotaszeg, making the folk arts and the rural landscape of Transylvania visually and experientially available to modern city-dwellers. By providing nature-based educational programs, the Zoo exposed Budapest's schoolchildren to traditional occupations, spaces, and animals, and cultivated personal, physical, and spiritual growth, all without ever having to leave the city. As a public space that married leisure, education, visual identity, and nationalism, the Budapest Zoo guided children toward becoming good Hungarian citizens.

With Kós and Zrumeczky's folk-inspired and hand-hewn animal houses as a backdrop, children were regularly invited to attend parties, performances, and seasonal activities at the Zoo. The Zoo held charitable events organized around children and offered discounts for their admission, and the proximity of Angolpark - the amusement park located just steps awaymeant that children could combine a day at the Zoo with rides, snacks, and entertainment. Unlike many other European zoos operating around the same time, the Budapest Zoo was framed as a place where children and their families could return often. Yet, despite attempts by directors and educators to preserve the Zoo as a contained space of childlike innocence, children were nevertheless implicated in many of the twentieth century's major political events; the fantasy of the Zoo as a pure and protected space was often interrupted by the harsh realities that occurred just outside. During times of political unrest and wartime violence, posters advertising the Budapest Zoo and its events offered visions of the Zoo as a space where animals and children were happy and free. In the 1914 poster "Winter Sports at the Zoo," smiling children ice-skate and sled around a jovial and childlike polar bear (image 8). Free from adult supervision, the happy group plays at the foot of a snowy hill, with a snow-covered Bird House in the background. Children, animals, the snow-covered hill, and vernacular-style architecture are the main elements in this image, and all are portrayed as allies and equals. But the joyousness of the image counters the struggle felt in the world outside the Zoo. By 1914, World War I had begun. The poster's text lists "reindeer, skating, sledding, sleighing, and shooting practice on ice," but it also advertises "daily reports," ostensibly providing wartime news to adult caretakers, who may be absent in the image, but whose presence and concerns were acknowledged within the poster's text.

In addition to built space, many of the most exciting Hungarian designs made for children are book illustrations. The multi-talented architect, graphic designer, and illustrator, Lajos Kozma (b. 1884) created a number of designs for children, including nursery furniture, interior 
Winick, Amber. "Lessons from Objects: Designing a Modern Hungarian Childhood 1890-1950.” Hungarian Cultural Studies. e-Journal of the American Hungarian Educators Association, Volume 8 (2015): http://ahea.pitt.edu DOI: 10.5195/ahea.2015.216

designs, as well as illustrated books. Kozma, together with Kós and Zrumeczky and a handful of other design school contemporaries, bonded over their strong interest in vernacular design as inspiration for their work. In fact, Kozma, Kós, and Zrumeczky were founding members of the group Fiatalok ['The Young Ones']. By this time, artistic interest in the folk arts was already in the air: Kalotaszeg was the subject of the first volume of Dezső Malonyay's (b. 1866) comprehensive five-volume publication, A Magyar nép müvészete ['Hungarian Folk Art' (1907)]. But while the designers enjoyed various professional successes throughout their lives, the decade after World War I was highly contentious for Hungarians, who would experience the disturbing after effects of war, revolutionary violence, and the dissolution of the AustroHungarian Monarchy. Though their image making during these early years was in synch, the start of World War I would mark a visual—and lifestyle — split for Kós, Zrumeczky, and Kozma. Each of the three designer's lives took a different course in wartime. Zrumeczky was assigned to a technical unit during World War I. In 1917, he contracted pleurisy and was sent to Budapest for treatment, finally passing away at the age of thirty-three (Ritook 2014). Kós, meanwhile, was closely linked to the Calvinist Church throughout his life, which provided an official organism for many of the designer's professional activities (Gall 2002: 24). Kós was drafted in 1915, but was soon discharged on request from the Ministry of Culture (Nastasă and Salat 2012: 4). Between 1917 and 1918, he was sent on a study trip to Istanbul, which resulted in Sztanbul, a monograph of drawings and prints, reflections, and remembrances (Gall 2002: 24).

Kozma was part of Hungary's affluent and well-assimilated Jewish community. From 1909 to 1910, Kozma lived in Paris and studied painting with Henri Matisse (Kinchin 2002: 75). But during World War I, he was an artillery officer for nearly four years. Much of this time was spent on front lines in Transylvania (Kinchin 2002: 77). While away from home in 1917, Kozma made a series of illustrations for his daughter, Zsuzsa. In 1921, the illustrations were reworked into a fairytale alphabet book and published with text by Hungarian writer, Frigyes Karinthy (b. 1887). The images feature Zsuzsa in fantastical Baroque interiors. As Juliet Kinchin has remarked about Kozma's project, "Accessing this fantastical dream world that he so playfully filled with light, color, and familiar furnishings must have helped him cope with the wartime situation" (Kinchin 2002: 83) (image 9).

In the summer of 1918, Kozma met Imre Kner (b. 1890), a Hungarian printer who, like Morris, had become disillusioned with industrial printing and bookmaking and sought to revive the values embodied in old Hungarian books (Haiman 1995: 44). Kozma would make an ideal collaborator. Though the turbulence the revolutionary violence of 1918-1919 threatened their project, they joined with literary historian György Király (b. 1865), an expert in Renaissance and Baroque Hungarian literature (Haiman 1995: 45). Just before Christmas of 1920, the Three Tiny Books were published by Kner's printing press (Haiman 1995: 45). These volumes reprieved fables, stories, and anecdotes from Renaissance and Baroque Hungary. Kner and Kozma jointly designed the typography and made a special series of stock Kner printing ornaments. Kozma sketched out the headlines, vignettes, initials, and illustrations and Kner contracted experienced woodcutters to reproduce Kozma's designs. The illustrations printed from the woodcuts were then colored by hand. In his collaboration with Kner, Kozma not only refined his typographic and graphic principles, but also explored his interest in Baroque. Writing about contemporary ornament in 1922, Kozma exclaimed:

Rather than animation, restlessness and what is finished, it is preparation, the growth of life, fever, driving force which finds delight as much in flashes of lightening as the burgeoning growth of fleshy tendrils, in short 
Winick, Amber. "Lessons from Objects: Designing a Modern Hungarian Childhood 1890-1950.” Hungarian Cultural Studies. e-Journal of the American Hungarian Educators Association, Volume 8 (2015): http://ahea.pitt.edu DOI: 10.5195/ahea.2015.216

the dynamic power of portrayal which is fundamentally related to Baroque ornament (Kozma 1922: 68-79).

By the early 1920s, Kozma was still working with ideas of folk culture and Hungarian mythology, but he also channeled Baroque into his designs. His name became synonymous with a style termed "neo-Baroque" or "folk Baroque" which was used to describe his architecture, interiors, furniture, textiles, as well as his graphic designs. To give the neo-Baroque a nationalistic dimension, contemporary commentators emphasized Baroque's association with the national hero, Rákóczi, a Transylvanian prince (Kinchin 1995: 80).

One of the best-loved and most popular Hungarian children's illustrators is Kató Lukáts (b. 1900). Lukáts studied at the School for Applied Arts in Budapest, but left after three years and never completed her degree. In 1925, she married Gyula Kaesz (b. 1897), an architect, interior designer, and teacher. Lukáts began her career in advertising, and by the 1930s, she was a highly sought after commercial designer, specializing in women's fashion illustrations, posters, magazine covers, cosmetics packaging, and wrapping papers (image 10). She also contributed to many of her husband's work in interior design projects, designing textiles or inlays for his furniture designs. With a confident hand and a bright palette often rendered in opaque gouache, her style was modern and chic, and she leant an air of sophistication to each of her design projects.

After World War II, the field of advertising was under the supervision of the Communist Party, forcing countless commercial artists and designers to find work elsewhere. In search of work, Lukáts re-branded herself as a children's book illustrator. In a manner that was both modern and seemingly timeless, Lukáts illustrated scores of Hungarian stories, fables, and poems. Published in 1950, Zengö ABC, an alphabet book that generations of Hungarian children owned and studied from, is typical of Lukáts' style - her illustrations are clean, bright, and confident. Her drawings show a vision of an uncomplicated Hungarian childhood, full of nature and animals, children dressed in peasant style clothing, or gathered around grandmotherly types in kerchiefs. Their houses are made of wood, and have decorated gates. Children are represented in each of the seasons: they are shown picking fruit and flowers in the spring, taking shelter from the rain in the fall, enjoying a lazy summer day and traversing wintery snow banks in a wooden sled decorated with a Hungarian tulip. The alphabetized pages show children playing blind man's bluff games, mending their shoes, harvesting plums, and embroidering with their grandmothers.

As an advertiser first and foremost, Lukáts's illustrations promote classical scenes of Hungarian childhood, free of political hardship or war. Yet while these rural, sentimental visions of are seemingly uncomplicated, Socialist realism lurked behind every image (see Crowley and Pavitt 2008). As in other Stalinist regimes in Central and Eastern Europe, following the communist takeover of Hungary, government agencies controlled cultural spaces and activities to ensure that party policy was observed (Kinchin and O'Connor 2014: 160). Although the Communist Party strictly controlled all aspects of private and public life, they placed a considerable emphasis on activities for children (Applebaum 2012: 149-173). The Communists under Stalin highlighted children in official propaganda, devoted significant funds to schools and other children's services, and supported children's organizations as a means of inculcating a sense of civic responsibility and collective identity. Whereas Hungarian nationalists had long championed the peasant, Stalinists easily adapted parallels between the peasant and the proletariat worker, especially in children's books. Lukáts's illustrations fit easily into official aesthetic requirements: namely, in that they featured children who were good citizens of 
Winick, Amber. "Lessons from Objects: Designing a Modern Hungarian Childhood 1890-1950.” Hungarian Cultural Studies. e-Journal of the American Hungarian Educators Association, Volume 8 (2015): http://ahea.pitt.edu DOI: 10.5195/ahea.2015.216

Hungary and in the larger family of the Soviet bloc. The characters and scenes are also distinctly Hungarian, and portray a sense of cultural continuity. Lukáts's illustrations, especially those from the 50s and 60s, typify this severely regulated aesthetic climate, where design was a tool for propaganda.

Lukáts's illustrations may have promoted rhetoric that would have fit the requirements of Communist officials - namely, for compliant children - but they also carry a tenderness, a sense of cultural continuity and a way of life that was in tune with nature, family, and Magyar lifeways. The popularity and endurance of the images reveal how attractive these ideas must have been for young Hungarians and their parents, like wishes for a childhood fulfilled.

Although my investigations took me from architecture to clothing, and from interior designs to book illustrations, each of the six objects and designs I examined demonstrate how successive generations of Hungarians negotiated issues of Hungarian identity, tradition, and modernity. As one might expect, the larger political and socioeconomic changes that occurred in twentieth century Hungary are reflected in the shifting alignment of Hungarian design vis-à-vis the world at large, a process that can be traced through the lives of designers and the things they designed. Such case-studies also reveal the extent to which adults try to guide children's viewpoints. Certainly, each of these designs reveal cultural priorities: a preference for strong, capable children who value their national heritage, and know familial and domestic duty as intimately as they do the natural world. Sometimes, designs can be tools of political manipulation, promoting at best self-confidence and patriotism, and at worst racism and xenophobia. Yet, in each case, designs made for children represent ways in which twentieth century Hungarians saw the future of their nation. Politicians, designers, design reformers, and craftspeople knew these designs would guide the nation toward a notion of a more perfect future.

\section{Acknowledgments}

I am grateful to the Fulbright Association and Fulbright Hungary for a research fellowship in 2013-2014, hosted by the Iparmüvészeti Múzeum. Colleagues at the Múzeum—in particular Reichart Dóra, Margittai Zsuzsi and Zsombor Jékely—provided guidance and access to a range of materials made for Hungarian children. They also offered stimulating conversation and introductions that enabled me to delve deeply into the topic. I am also thankful to Paul Stirton, my advisor at the Bard Graduate Center, and Juliet Kinchin, who both inspired and encouraged my work on Hungarian design and laid important groundwork for my research. 


\section{Images}

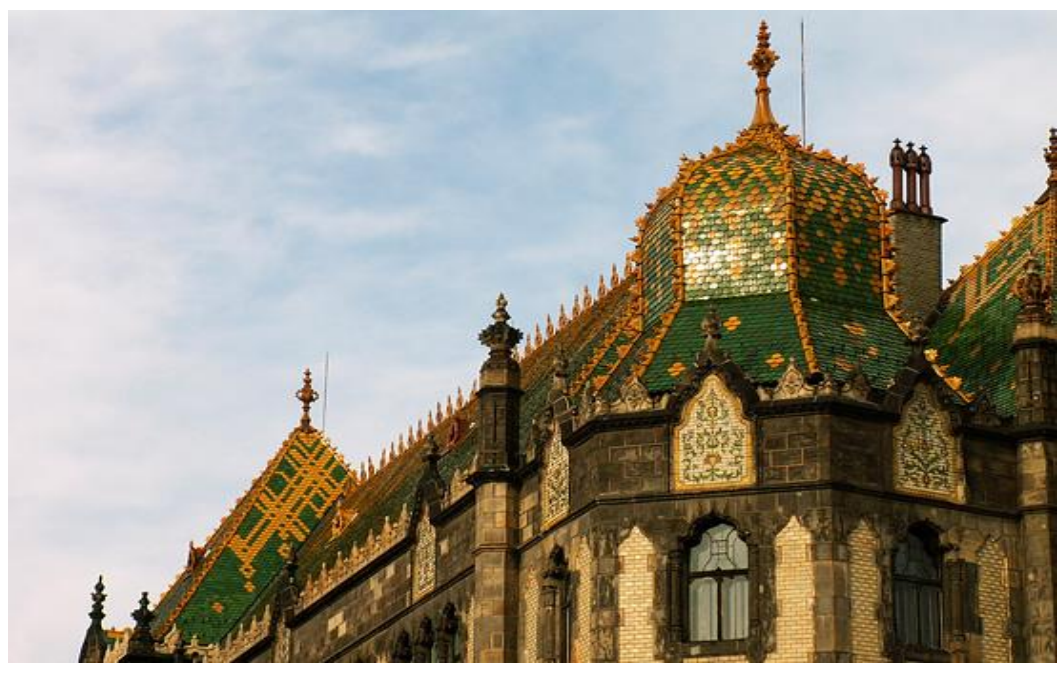

Image 1. Photograph of Ödön Lechner's Iparmüvészeti Múzeum ['the Museum of Applied Arts']. Image: author's own, May 2012.

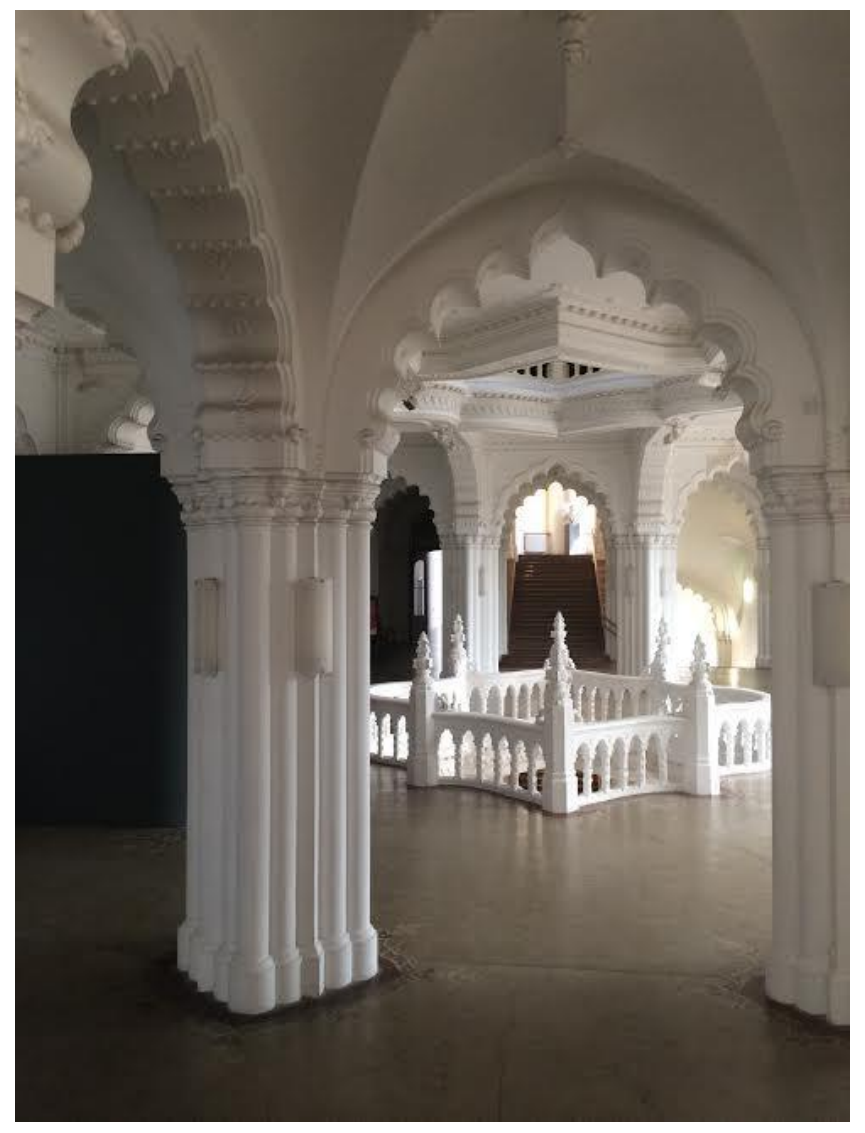

Image 2. Photograph of the upper interior of Ödön Lechner's Iparmüvészeti Múzeum ['the Museum of Applied Arts']. Image: author's own, June 2014. 


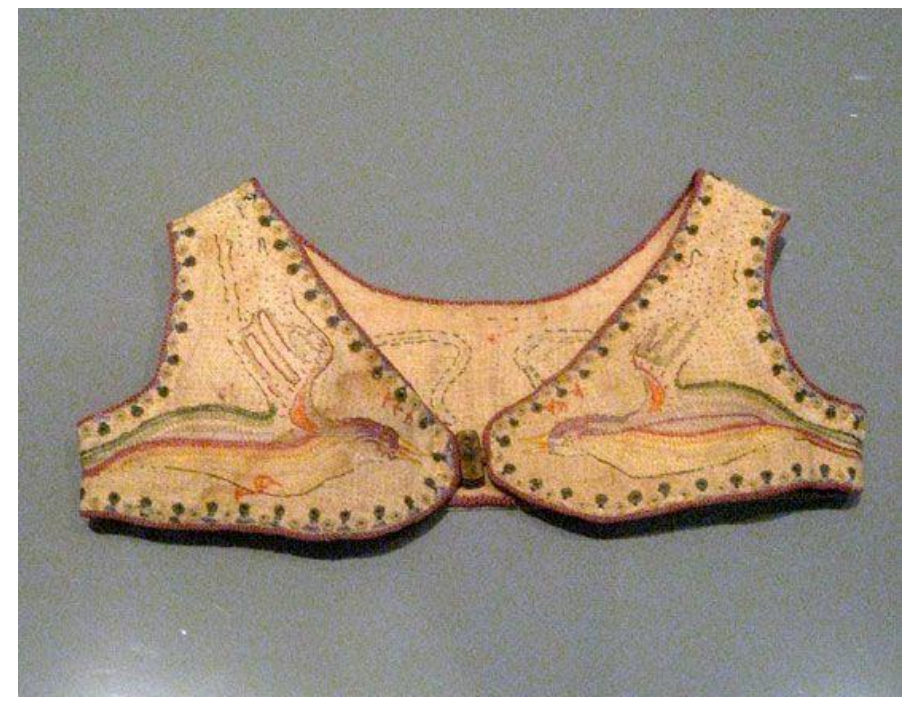

Image 3. Laura Kriesch, cotton embroidery on linen, 51/8 x 11 ”. In the collection of the Gödöllö Town Museum.

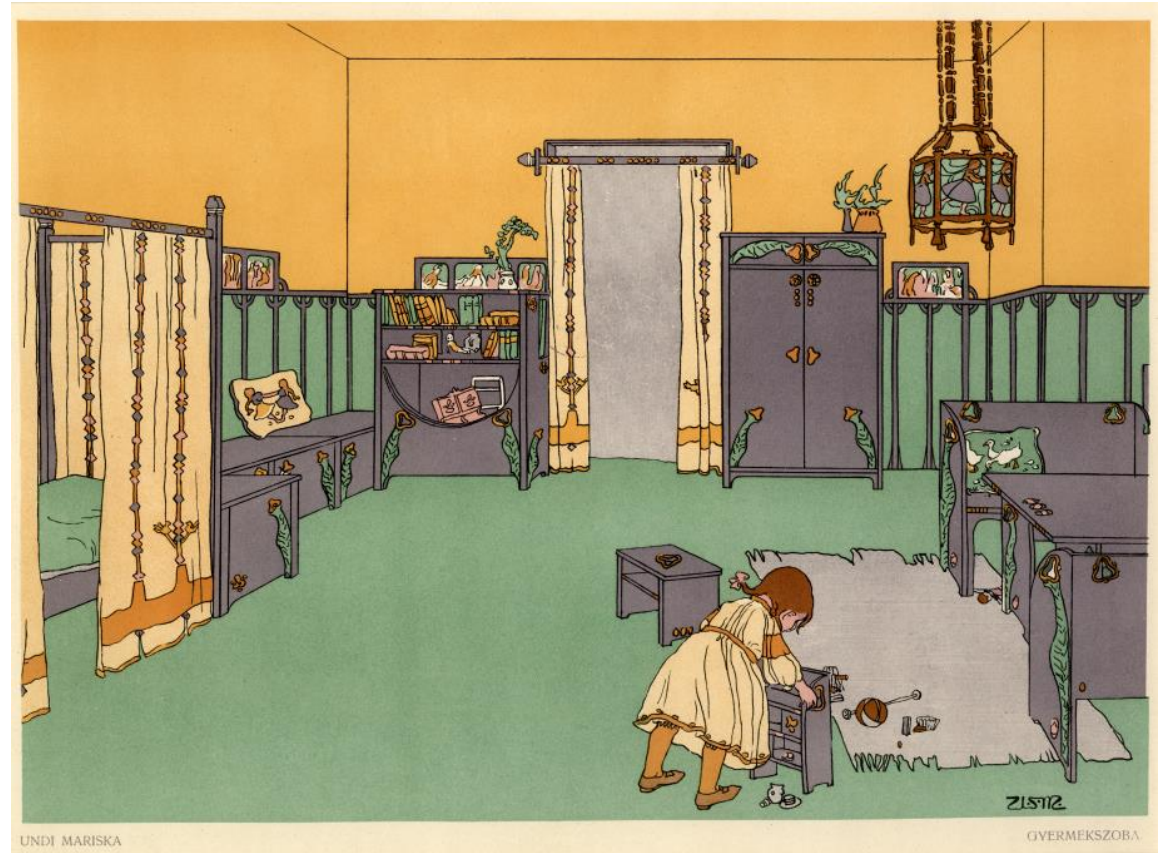

Image 4. Mariska Undi, Design for a child's room. 1903. Lithograph, 11 5/8 x 16 1/4. Published by the Hungarian Ministry of Culture in Mintalapok (1903). In the collection of the Iparmüvészeti Múzeum. 
Winick, Amber. "Lessons from Objects: Designing a Modern Hungarian Childhood 1890-1950." Hungarian

Cultural Studies. e-Journal of the American Hungarian Educators Association, Volume 8 (2015): http://ahea.pitt.edu DOI: $10.5195 /$ ahea.2015.216

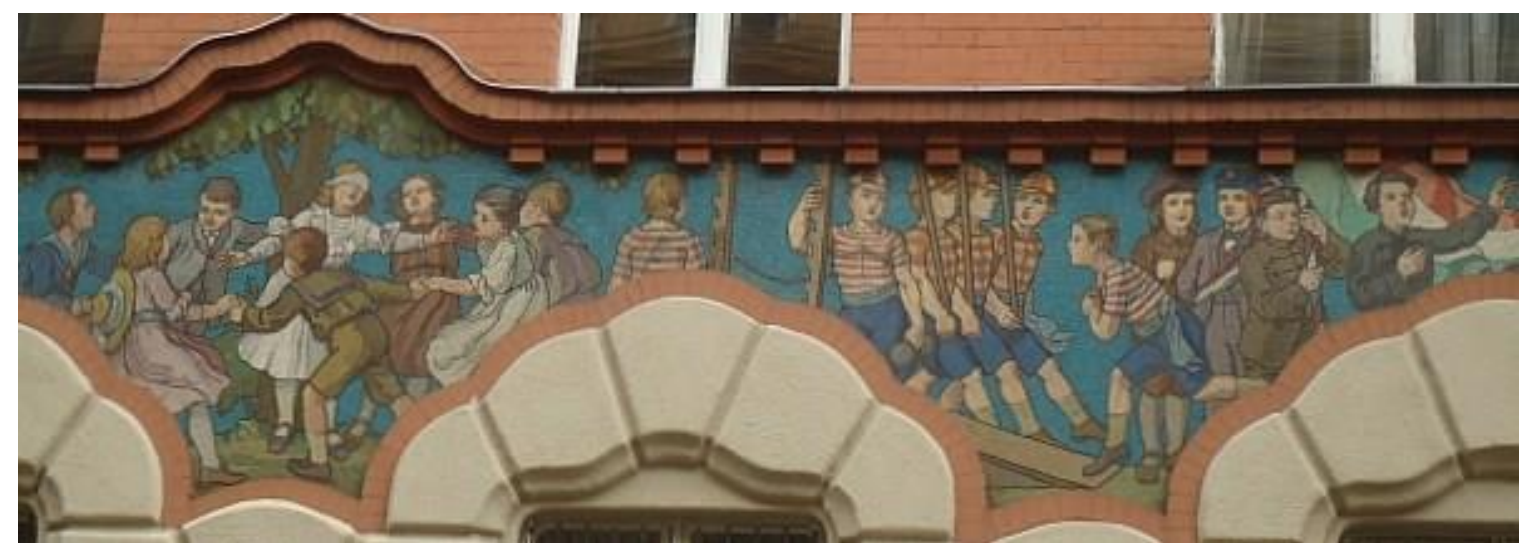

Image 5. Photograph of the upper exterior windows and mosaic façade on Ármin Hegedüs's Dob utca school. Image: author's own, June 2014.

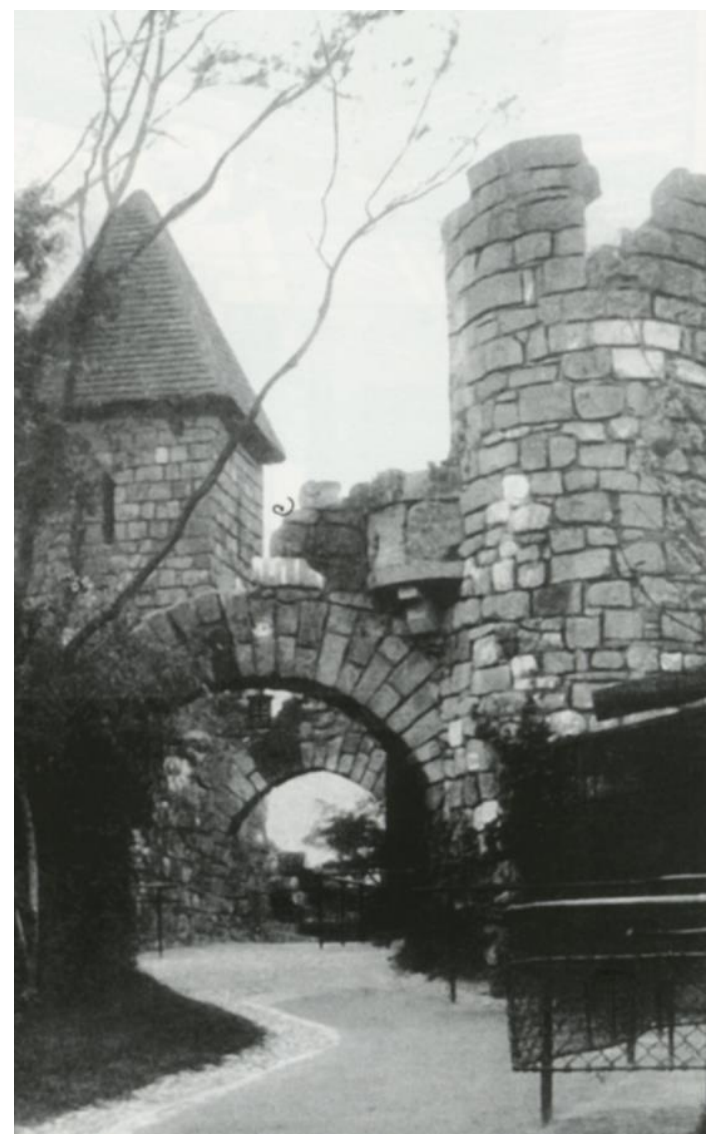

Image 6. Image of the Budapest Zoo's Castle Ruins, circa 1912. In the collection of the Budapest Zoo. 


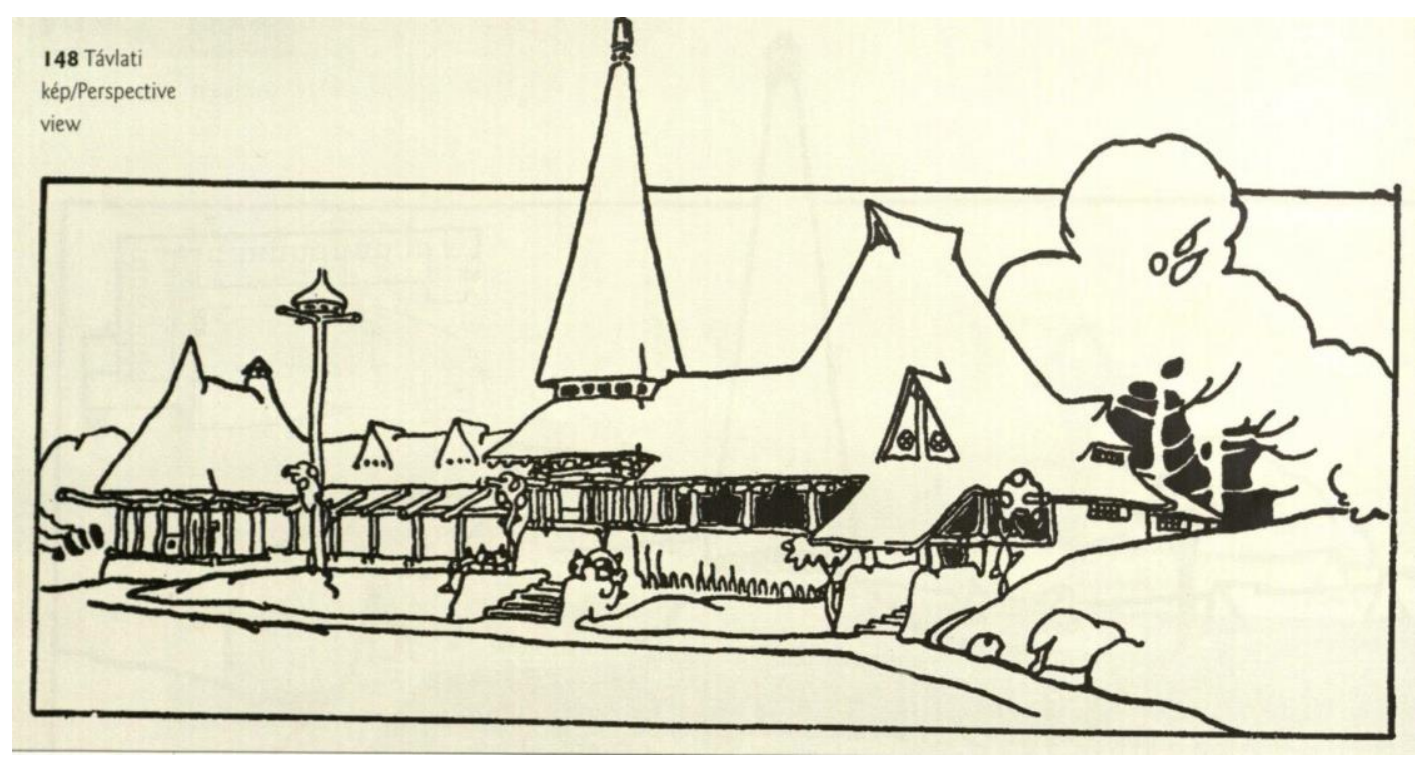

Image 7. Károly Kós, Bird House, ink drawing for the architectural commission of the Budapest Zoo, circa 1908-1912. Reproduction of original drawings in the collection of the Budapest Zoo.

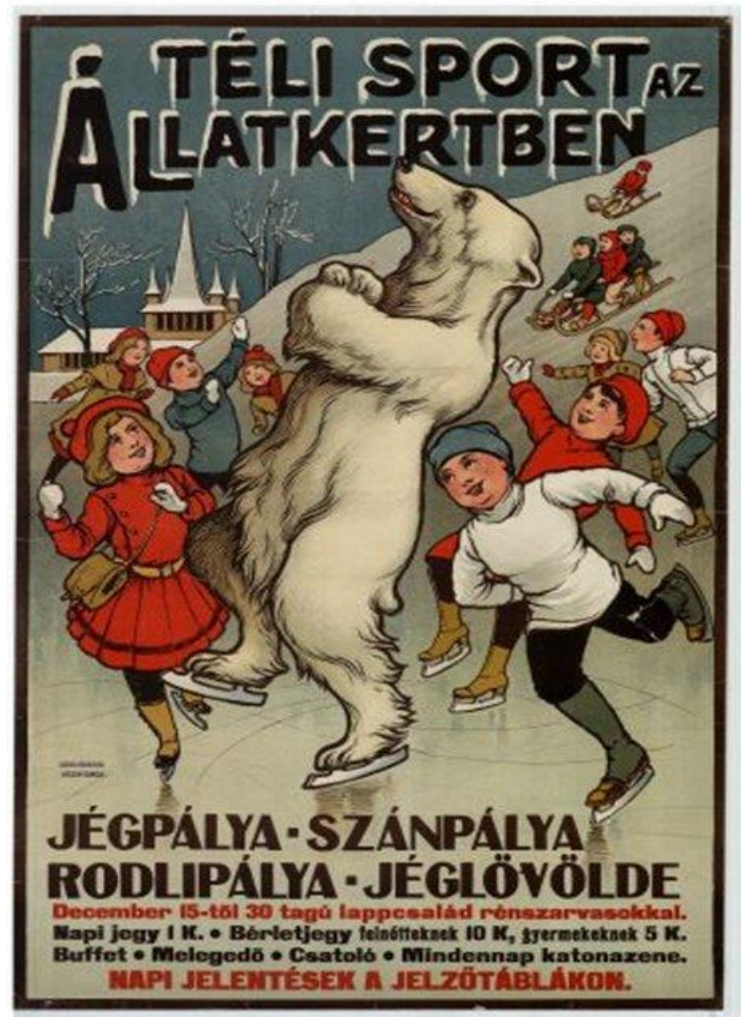

Image 8. Unknown designer's poster for the Budapest Zoo, circa 1914. Chromolithograph. Poster in the collection of the Budapest Zoo. 
Winick, Amber. "Lessons from Objects: Designing a Modern Hungarian Childhood 1890-1950." Hungarian

Cultural Studies. e-Journal of the American Hungarian Educators Association, Volume 8 (2015): http://ahea.pitt.edu DOI: 10.5195/ahea.2015.216

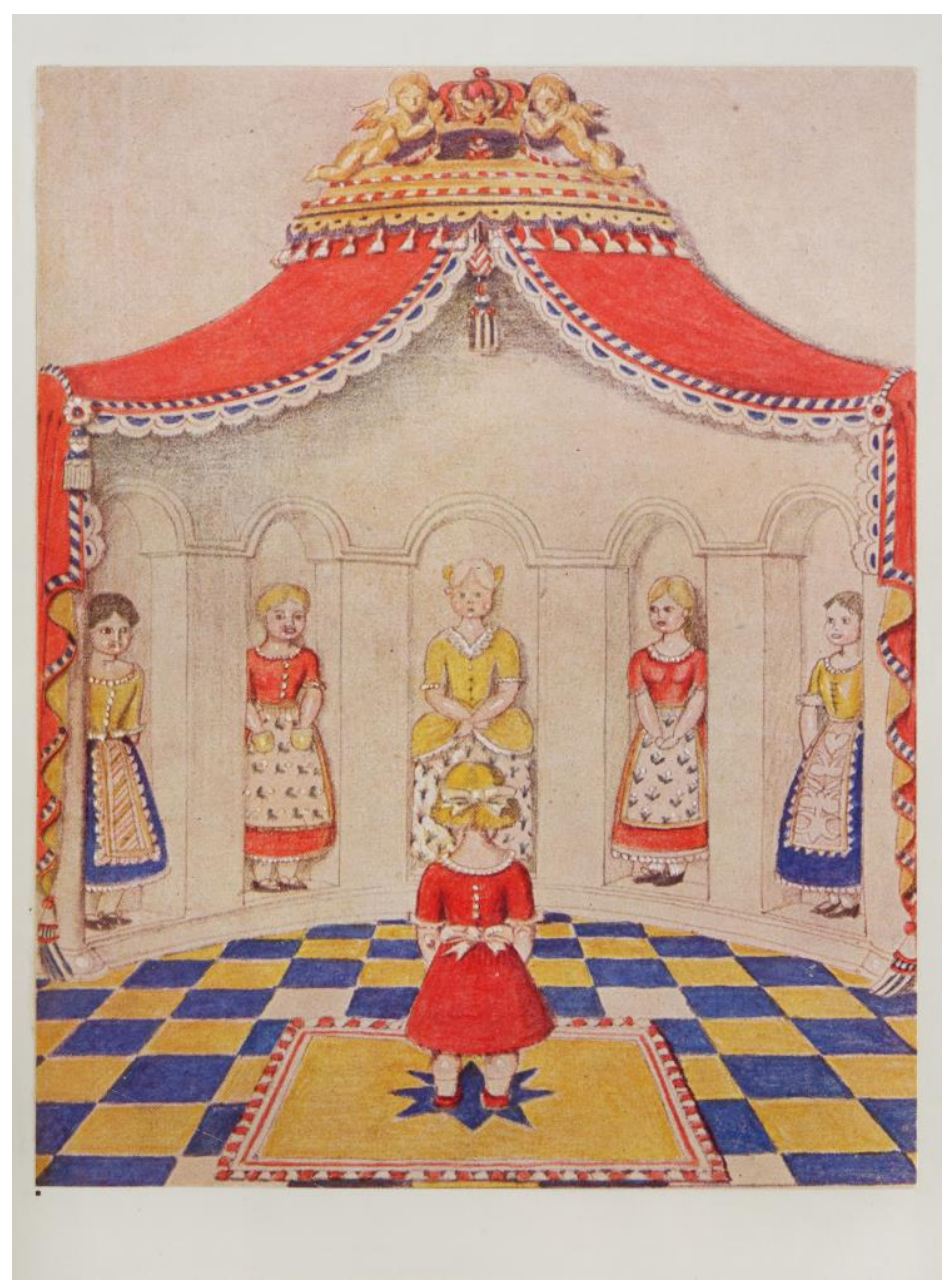

Image 9. Lajos Kozma, illustrations from the fairytale Zsuzsa Bergengóciában (Susie in Fairyland), 1917.

(Budapest: Sacelláry Kiadó, 1921).

In the collection of the Iparmüvészeti Múzeum. 
Winick, Amber. "Lessons from Objects: Designing a Modern Hungarian Childhood 1890-1950." Hungarian

Cultural Studies. e-Journal of the American Hungarian Educators Association, Volume 8 (2015): http://ahea.pitt.edu DOI: $10.5195 /$ ahea.2015.216

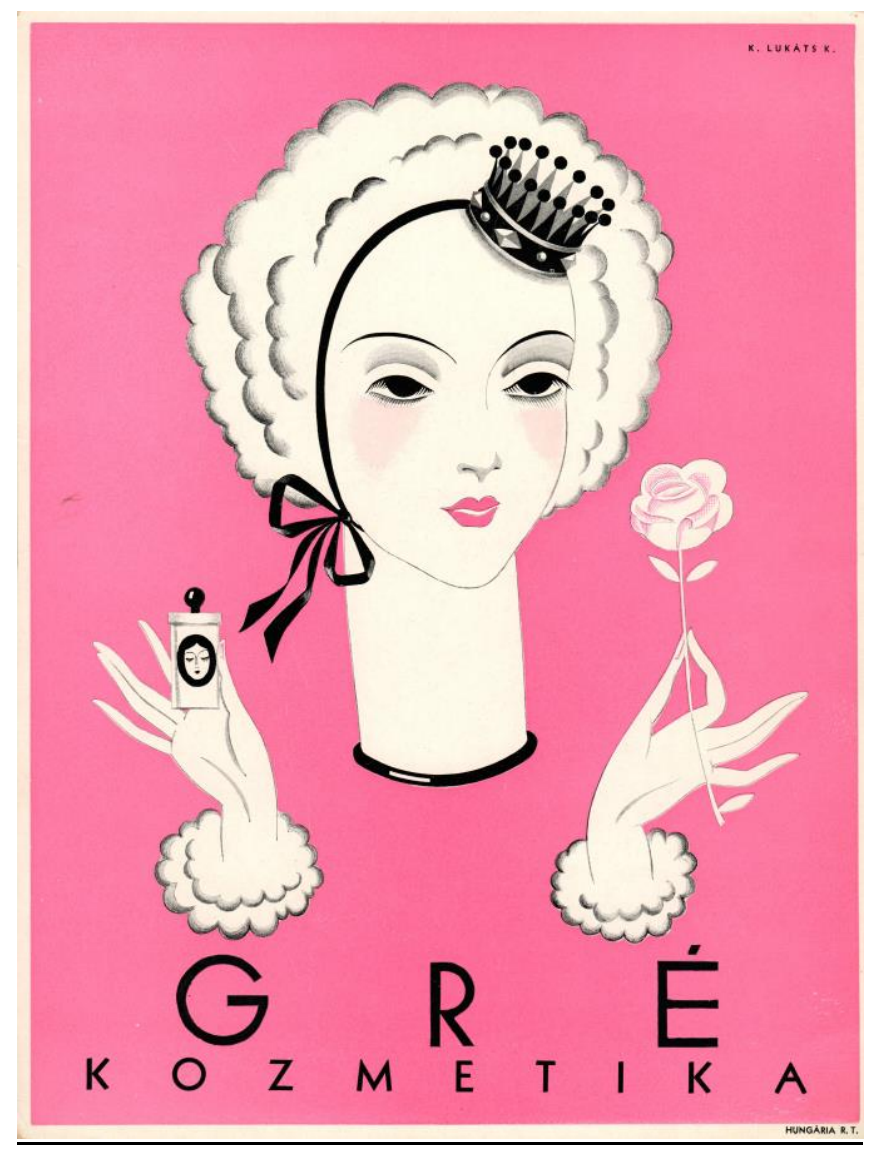

Image 10. Kató Lukáts design for Gré cosmetics package, circa 1933. In the collection of the Iparmüvészeti Múzeum. 

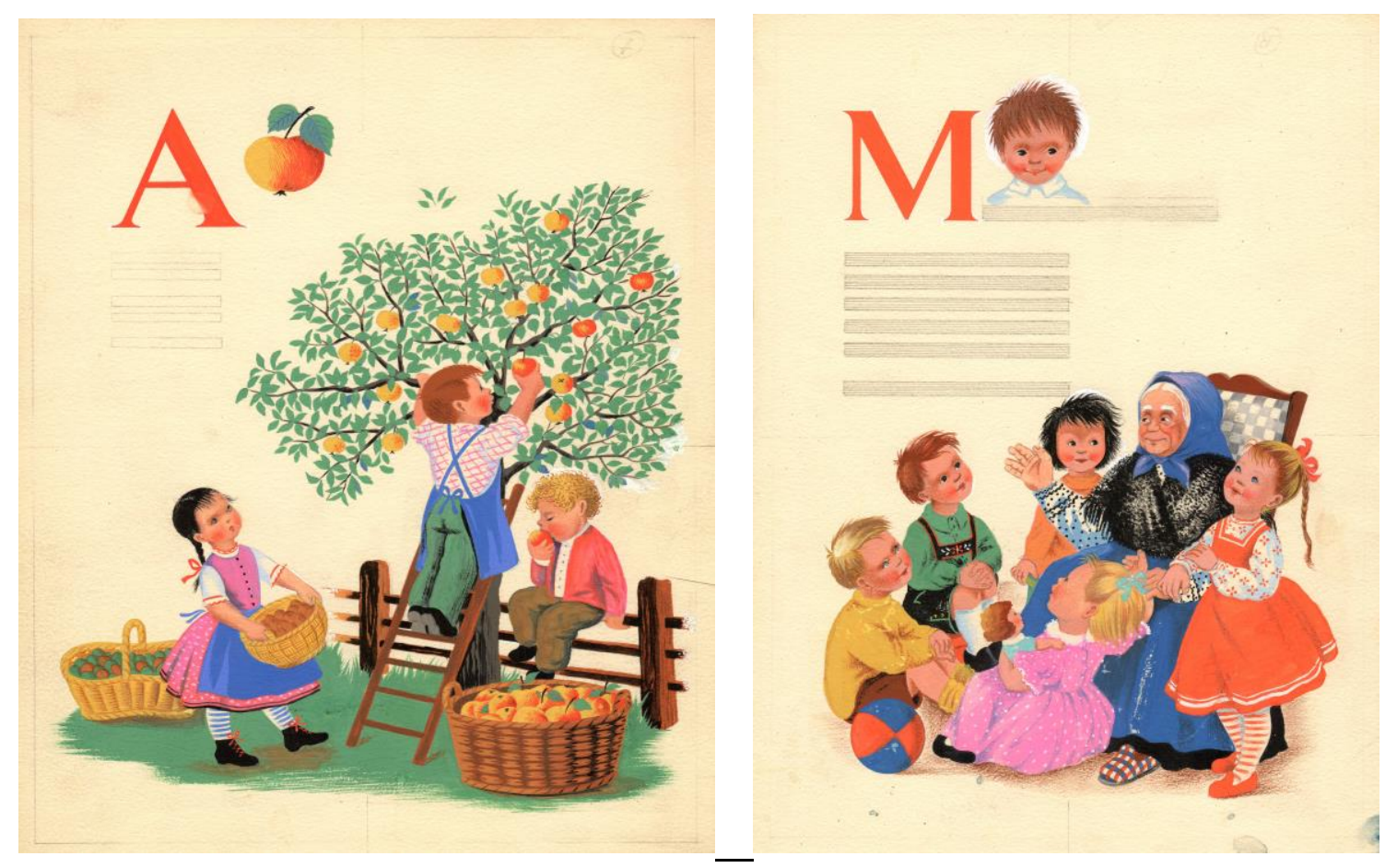

Images 11 and 12. Kató Lukáts, original book illustrations for Zengő ABC, circa 1950. In the collection of the Iparmüvészeti Múzeum.

\section{Works Cited}

Anderson, Benedict. 1983. Imagined Communities: Reflections on the Origin and Spread of Nationalism. London: Verso.

Applebaum, Anne. 2012. Iron Curtain: The Crushing of Eastern Europe 1944-1956 New York: Doubleday.

Baratay, Eric and Elisabeth Hardouin-Fugier. 2002. Zoo: A History of Zoological Gardens in the West. London: Reaktion Books Ltd.

Crowley, David and Jane Pavitt, eds. 2008. Cold War Modern Design 1945-1970. London: V\&A Publishing ; New York : Distributed by Harry N. Abrams.

Froebel, Fredrich. 1826. Die Menschenerziehung. Keilhau, Germany: Verlag der Allgemeinen Deutschen Erziehungsanstalt. Published in English as The Education of Man, trans. Josephine Jarvis. 1885. New York: A. Lovell.

Gellér, Catherine and Catherine Bitter. 1987. Gödöllö Artists' Colony. Budapest: Corvina. Gall, Anthony. 2002. Károly Kós: The Workshop of Károly Kós, Essays and Archives. Budapest: Mundus Hungarian University Press Kiadó.

Gutman, Marta and Ning de Coninck-Smith. 2008. "Good to Think With: History, Space, and Modern Childhood." In Designing Modern Childhoods: History, Space, and the Material Culture of Children. Eds., Marta Gutman and Ning de Coninck-Smith. New Brunswick, N.J.: Rutgers UP. 
Haiman, György. 1995. "Imre Kner and the Revival of Hungarian Printing." In Design History: An Anthology. Ed., Dennis Doorden. Cambridge, Mass.: MIT Press.

Howard, Jeremy. 1996. Art Nouveau: International and National Styles in Europe. Manchester and New York: Manchester UP.

Keseru, Katalin and Peter Haba, eds. 2005. The Beginnings of Modernism in Central European Architecture: Polish, Czech, Slovak and Hungarian Architectural Writings at the Turn of the 20th Century. Budapest: Palatinas Publishing House and Ernst Museum.

Key, Ellen. 1909. Century of the Child. New York : G.P. Putnam's Sons.

Kinchin, Juliet. 2002. "Modernity and Tradition in Hungarian Furniture, 1900-1938: Three Generations." The Journal of Decorative and Propaganda Arts 24: 65-93.

Kinchin, Juliet and Aidan O'Connor, eds. 2012. Century of the Child: Growing by Design 19002000. New York: Museum of Modern Art.

Kozma, Lajos. 1922. "Individuality and Tradition.” Gyoma: Kner Almanach.

Lechner, Ödön. 1906. "Magyar mủvészet nem volt, hanem lesz" ['Hungarian Art Hasn’t Been, but Will Be']. Budapest: Müvészet.

Malonyay, Dezső. 1907. A magyar nép müvészete. Budapest : Helikon.

Nastasă, Lucian and Levente Salat, eds. "Maghiarii din România şi etica minoritară" [Hungarians in Romania and Minority Ethics] (1920-1940), at the Ethnocultural Diversity Resource Center. Open Society Foundation Romania; retrieved 4/28/12.

Persányi, Miklós. 2003. The Budapest Zoo: Designed for Nature. Budapest: Fővárosi Állat-és Növénykert.

Ritook, Pál. Interview conducted on July 12, 2014.

Switzer, T. 2003. "Hungarian Self-Representation in an International Context: The Magyar Exhibited at International Expositions and World's Fairs" Facos \& Hirsch, eds. Art, Culture and National Identity in Fin-de-Siècle Europe. Cambridge: Cambridge University Press. 